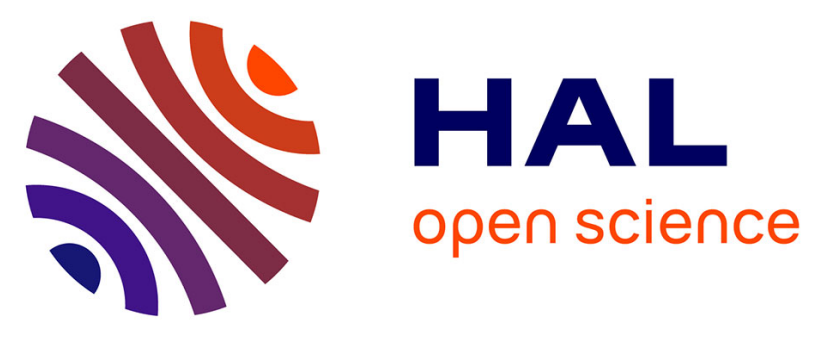

\title{
Mother-to-child HIV transmission despite antiretroviral therapy in the ANRS French Perinatal Cohort.
}

\author{
Josiane Warszawski, Roland Tubiana, Jérôme Le Chenadec, Stephane \\ Blanche, Jean-Paul Teglas, Catherine Dollfus, Albert Faye, Marianne \\ Burgard, Christine Rouzioux, Laurent Mandelbrot, et al.
}

\section{To cite this version:}

Josiane Warszawski, Roland Tubiana, Jérôme Le Chenadec, Stephane Blanche, Jean-Paul Teglas, et al.. Mother-to-child HIV transmission despite antiretroviral therapy in the ANRS French Perinatal Cohort.. AIDS. Official journal of the international AIDS Society, 2008, 22 (2), pp.289-99. 10.1097/QAD.0b013e3282f3d63c . inserm-00204104

\section{HAL Id: inserm-00204104 https://www.hal.inserm.fr/inserm-00204104}

Submitted on 6 Jul 2009

HAL is a multi-disciplinary open access archive for the deposit and dissemination of scientific research documents, whether they are published or not. The documents may come from teaching and research institutions in France or abroad, or from public or private research centers.
L'archive ouverte pluridisciplinaire HAL, est destinée au dépôt et à la diffusion de documents scientifiques de niveau recherche, publiés ou non, émanant des établissements d'enseignement et de recherche français ou étrangers, des laboratoires publics ou privés. 


\section{HAL author manuscript}

TITLE

Mother-to-child HIV transmission despite antiretroviral therapy in the ANRS French Perinatal Cohort

J. Warszawski, MD PHD ${ }^{(\mathrm{a}, \mathrm{b}, \mathrm{c}, \mathrm{d})}$, R. Tubiana, MD ${ }^{(\mathrm{e}, \mathrm{f})}$, J. Le Chenadec ${ }^{(\mathrm{a}, \mathrm{d})}$, S.Blanche, MD ${ }^{(g, h)}$, J.P. Teglas ${ }^{(a, d)}$, C. Dollfus, MD ${ }^{(i)}$, A. Faye, MD ${ }^{(j)}$, M. Burgard, MD ${ }^{(g, k)}$, C. Rouzioux, MD PharmD PHD ${ }^{(\mathrm{g}, \mathrm{k})}$, L. Mandelbrot, MD ${ }^{(\mathrm{a}, \mathrm{l}, \mathrm{m})}$; for the ANRS French Perinatal Cohort

(a) Inserm, U822, Le Kremlin-Bicêtre, F-94276 France

(b) Univ Paris-Sud, Faculté de Médecine Paris-Sud, Le Kremlin-Bicêtre, F-94276

(c) AP-HP, Hopital Bicêtre, Epidemiology and Public Health Service, F-94276

(d) INED, Paris, F-75020

(e) AP-HP, Hôpital Pitié Salpêtrière, Department of infectious diseases, Paris, F-75651 France

(f) INSERM, U543, Paris

(g) EA 3620, Univ Paris Descartes 5

(h) AP-HP, Necker Hospital, Unité d’Immunologie Hématologie Pédiatrique, Paris, F-75015 France

(i) AP-HP, Hôpital Trousseau, Service d'Hématologie et d'oncologie pédiatrique, Paris, F-75571 France

(j) AP-HP, Hôpital Robert Debré, Service de Pédiatrie Générale, Paris, F-75019 France

(k) Virology Department; AP-HP, Necker Hospital, Paris, F-75015 France

(l) Univ Paris 7, Paris, France

(m) AP-HP, Hôpital Louis Mourrier, Gynecology and obstetrics department, Colombes, F-92700 France

\section{Corresponding author : Josiane Warszawski}

INSERM, INED U822

82, rue du Général Leclerc, 94276 Le Kremlin Bicêtre cedex, France

Mail : warszaws@vjf.inserm.fr

Tel : 33 (1) 45212286 / Fax : 33 (1) 49595399

Word count: 3495 words / Version: Novembre, $14^{\text {th }}, 2007$ 


\begin{abstract}
Objective: To identify factors associated with mother-to-child HIV-1 transmission (MTCT) from mothers receiving antenatal antiretroviral therapy.

Design: The French Perinatal Cohort (EPF), a multicenter prospective cohort of HIV infected pregnant women and their children.

Methods: Univariate analysis and logistic regression, with child HIV status as dependant variable, were conducted among 5271 mothers who received antiretroviral therapy during pregnancy, delivered between 1997 and 2004 and did not breastfeed.

Results: The MTCT rate was 1.3\% (67/5271 ; 95\% confidence interval [CI], 1.0 -1.6). It was as low as $0.4 \%(5 / 1338$; 95\% CI, $0.1-0.9)$ in term births with maternal HIV-1 RNA level at delivery below 50 copies/mL. MTCT increased with viral load, short duration of antiretroviral therapy, female gender and severe premature delivery: $6.6 \%$ before 33 weeks versus $1.2 \%$ at 37 weeks or more $(\mathrm{p}<0.001)$. The type of antiretroviral therapy was not associated with transmission. Intrapartum therapy was associated with 4-fold lower MTCT $(\mathrm{p}=0.04)$ in case of virological failure (> 10000 copies $/ \mathrm{mL}$ ). Elective cesarean section tended to be inversely associated with MTCT in the overall population, but not in mothers who term delivered with viral load < 400 copies/mL (OR: 0.83; 0.29-2.39; $\mathrm{p}=0.37$ ). Among them, only duration of antenatal therapy was associated with transmission (OR by week: 0.94; 0.90-0.99; $\mathrm{p}=0.03$ ).

Conclusions: Low maternal plasma viral load is the key factor for preventing mother-to-child transmission. Benefits in term of MTCT may be expected from early antiretroviral prophylaxis. Potential toxicity of prolonged antiretroviral use in pregnancy should be evaluated.
\end{abstract}

Key words: HIV, prevention of mother-to-child transmission, epidemiology, cohort, public health 
Over the decade following the landmark PACTG076/ANRS024 American-French trial in 1994, a spectacular decrease in mother-to-child transmission of HIV-1 (MTCT) has been obtained in industrialized countries [1]. Transmission rates on the order of $1-2 \%$ have been reported for several years [2-5]. While these results were first obtained using zidovudine with elective cesarean section, or a combination of zidovudine and lamivudine, the more recent consensus [6, 7] is to use highly active antiretroviral therapy (HAART) for the prevention of transmission, even in women without an indication for themselves. A number of specific considerations concerning the use of such aggressive regimens during pregnancy still need to be addressed, including optimal use of HAART in reducing the risk for perinatal transmission, effects on pregnancy outcome,[8-14] and whether elective cesarean is required in women receiving active therapy who have an undetectable plasma viral load at delivery [4, 12, 15-18]

Our objective was to estimate the MTCT rate and to evaluate the role of the various components of prophylaxis in the HAART era. At the opposite of most of the studies which included mothers who failed to receive any prophylaxis, the large number of mother-child pairs included in the French Perinatal Cohort provided the opportunity to focus on exclusively women who received antiretroviral therapy (ART) during pregnancy, especially with no obvious potential risk factors such as prematurity or virological failure at delivery.

\section{Subjects and Methods}

The French Perinatal Cohort (EPF)

Since 1986, the EPF has prospectively enrolled HIV-infected women who delivered in 90 centers throughout France, except in case of parental refusal. Children were followed up according to recommended standards of care [7], including clinical and biologic examination at birth, 1, 3, 6, 12 and 18-24 months, and then every 6 months for infected children, as previously reported [19]. No specific recommendation for HIV treatment and obstetrical care was made for women included in the cohort, although French national guidelines for prevention of MTCT were regularly published and updated[7]. The national policy since 1993 is to offer universal 
voluntary HIV testing as a part of prenatal care. Antenatal prophylaxis was initially based on zidovudine monotherapy or on dual nucleosidic therapy since 1997, with elective cesarean section according to risk/benefit evaluation. HAART was recommended to mothers with viral load above 10000 copies/mL in 2002 and to all mothers in 2004. Since 2002, elective cesarean section was not recommended for those who delivered under HAART with viral load below 400 copies/mL. In all cases, intrapartum zidovudine infusion and neonatal prophylaxis were recommended. This cohort study was approved, according to French laws, by the Hôpital Cochin IRB and the French computer database watchdog commission (Commission Nationale de l’Informatique et des Libertés).

\section{Study population}

All HIV-1 infected women who delivered in mainland France EPF sites between January 1, 1997 and December 31, 2004 were included if they met the following criteria: (1) they received at least one antenatal ART at any time during pregnancy (except exclusive intrapartum prophylaxis); (2) they did not breastfeed (99.8\% of treated mothers); (3) the child's infection status was documented. Breastfeeding status was recorded during the postnatal hospitalization, and at each protocol visit. An infant was considered as infected if HIV-1 was detected by virologic tests on two separate samples (HIV1-PCR DNA or HIV RNA or PBMC viral culture or p24 antigenemia) or if anti-HIV1 antibodies detected by ELISA and Western Blot persisted after 18 months of age. An infant was considered as non infected if virologic tests were negative on two separate samples, of which at least one taken after termination of the neonatal prophylactic treatment or if serological testing was negative after 18 months. Laboratory tests were done on sites. HIV-1 RNA quantification in plasma were assessed by either the Roche Amplicor Monitor Test version 1.5 (Roche Diagnostic Systems, Basel, Switzerland) or branched DNA (Quantiplex, Versant, Bayer HealthCare, Tarrytown, USA); HIV-1 PCR DNA in PBMC were performed using the Roche Amplicor Monitor Test with modifications as described [20], or using the real time PCR following the ANRS method [21]. Lastly, for few specific cases, PBMC viral culture was performed as described[22]. 
Among the 6587 HIV-1 infected women who delivered in the study period, 219 declined enrollment or terminated pregnancy, 118 were infected by HIV-2 exclusively, 226 did not receive antenatal ART (including 124 who received intrapartum ART prophylaxis), 12 breastfed. For 472 mothers, ART or breastfeeding status were missing, mostly due to delay in the return of questionnaires not related to maternal or children characteristics. Among the 5540 mothers who received ART and did not breastfeed, the child's HIV status could not be established for 42 stillbirths, 14 neonatal deaths, and for 213 (3.8\%) children because of incomplete virological data. For 117 multiple pregnancies, only the first born was included for estimation of the transmission rate. Overall, 5271 mother-child pairs, from 77 sites, were enrolled in analysis performed on data updated in January, 2007.

\section{Variables}

We recorded demographics including geographical origin, gestational age at booking visit in the obstetrical center, levels of plasma HIV1 RNA and CD4 cell count nearest to the time of delivery no more than 7 days after delivery, type and number of antiretroviral combinations received during pregnancy, mode of delivery (vaginal, emergency cesarean section or elective cesarean section, defined as before labor and before rupture of the membranes), and gestational age at delivery. Adherence was not recorded.

The last combination of ART prescribed before delivery was considered for analysis. It was categorized into three classes: monotherapy of nucleoside reverse transcriptase inhibitor (NRTI), almost exclusively with zidovudine, dual-drug therapy (two NRTI, mostly zidovudinelamivudine), or HAART (three or more drugs of any class). The antenatal ART duration was calculated as the number of weeks between the first initiation of antenatal ART and delivery. When a treatment interruption of at least 15 days was prescribed for women who were receiving ART at the onset of pregnancy, the antenatal ART duration was calculating beginning at reintroduction of ART. 
Maternal intrapartum prophylaxis was classified as none versus intravenous zidovudine and/or single-dose nevirapine. Neonatal prophylaxis initiated within 3 days, was classified as: none or zidovudine monotherapy or 2 or more antiretroviral drugs.

\section{Statistical analysis}

We first studied whether viral load and prematurity were related to transmission, independently of one another and of other factors likely to play a part in the maternal transmission of HIV. Percentages were estimated with their exact 95\% confidence intervals and compared by using Chi-square or 2-tailed Fisher exact test and continuous variables by Student or Wilcoxon rank test. Interaction between prematurity and viral load was investigated in stratified analysis. We assessed, for all births, term births and term births with viral load $<400$ copies $/ \mathrm{mL}$, the validity of linear assumption between transmission rate and duration of ART by fitting a generalized additive model (GAM) with S+ software [23], estimated by smoothing cubic splines [24].

A backward stepwise logistic regression was performed with the child's HIV status as the dependant variable. The significance p-value level for removal was fixed to 0.25 , using the likelihood-ratio test. The initial model included four groups of non collinear variables. The first group represented each component of prophylaxis strategy: duration of antenatal ART, type of last ART, mode of delivery, intrapartum prophylaxis, and type of neonatal prophylaxis. Type of first antenatal ART and time of initiation, number of changes during pregnancy, or duration of last antenatal ART were analyzed but not included in the final model because of colinearity. The second group of variables included the last viral load and CD4 cell count, which depended not only on the antenatal prophylaxis but on their level at starting pregnancy, unrecorded for most of these women. The third group included prematurity and gender of neonate. The fourth group comprised available characteristics potentially related to access or adherence to care management: year of delivery, parity, maternal age, geographical origin, active drug use and gestational age at booking.

We then excluded premature births ( $<37$ weeks) to perform stepwise logistic regressions in two subgroups, according to virological failure (viral load $\geq 10000$ copies $/ \mathrm{mL}$ ) or success at 
delivery ( $<400$ copies $/ \mathrm{mL}$ ), which represented respectively $7 \%$ and $54 \%$ of the whole study population.

Analyses were conducted using the STATA software [25] $. \mathrm{P}<0.05$ was used to determine statistical significance.

\section{Results}

\section{Characteristics of the population}

Overall, 5271 eligible mother-child pairs with deliveries between 1997 and 2004 were enrolled. At end-point, the median follow up for included children was 19 months (interquartile range:1524). The use of HAART increased from 3\% in 1997 to 53\% in 2001 and 79\% in 2004, while low maternal viral load at delivery ( $<400$ copies $/ \mathrm{ml}$ ) increased from $47 \%$ to $79 \%$. During that period, CD4 cell count remained stable ( $10 \%$ below 200 cells $/ \mathrm{mm}^{3}$ and $68 \%$ for 350 or over). In 2004, 54\% of mothers who were receiving HAART as last antenatal ART delivered with undetectable HIV-RNA level $(<50 \mathrm{c} / \mathrm{mL})$. Overall, 19\% of treated women were receiving monotherapy, 33\% dual-drug therapy, and 48\% HAART at delivery (Table 1). The HAART combination included two NRTI and a Protease inhibitor (PI) in 73\% of cases, two NRTI and a Non Nucleoside Reverse Transcriptase Inhibitor (NNRTI) in 17\%, NRTI, PI and NNRTI in 3\% and three or more NRTI exclusively in 7\%. The proportion of elective cesarean increased from $14 \%$ in 1997 to $56 \%$ in 2000 and tended to decrease to $41 \%$ in 2004 , whereas if was stable for emergency cesarean section (29\%). Ninety six percent received intrapartum prophylaxis, which was intravenous zidovudine alone or associated with single dose of nevirapine in $6 \%$ of cases. All neonates, except $0.7 \%$, started within the 3 days after birth a 4 to 6 weeks course of postnatal prophylaxis, mainly zidovudine monotherapy (76\%). Characteristics according viral load at delivery are presented in table 1 .

\section{Risk factors according to gestational age at delivery}


Among the 5271 neonates, 67 were infected, an overall MTCT rate of 1.3\% (95\% CI: 1.0 -1.6).

The univariate analysis (Table 2) showed a significant association with prematurity $(\mathrm{p}<0.001)$, HIV1 RNA level $(\mathrm{p}<0.001)$, CD4 cell count $(\mathrm{p}<0.001)$, and duration of ART during the pregnancy $(\mathrm{p}<0.001)$. The transmission rate was 6 times higher for neonates born before 33 weeks (6.6\%; 95\%CI: 2.9-12.5) than for full-term infants (1.1\%; 95\%CI: $0.8-1.5)$, but was not increased for those born between 33 and 36 weeks (1.2\%; 95\%CI: 0.5-2.5). The rate increased with delivery viral load in term $(\mathrm{p}<0.001)$ as well in premature births $(\mathrm{p}<0.001)$, with no significant interaction between viral load and prematurity ( $\mathrm{p}=0.18$; fig 1): overall, the rate was 0.6\% (95\%CI: $0.4-0.9$ ) below $400 \mathrm{c} / \mathrm{mL}$, reached 1.5\% (95\%CI: $0.8-2.5)$ between 1,000 and 10,000 c/mL, and 6.8\% (95\%CI: 4.6-9.6) over 10,000 c/mL; however, among severe premature births, the rate passed from $1.7 \%$ below $400 \mathrm{c} / \mathrm{mL}$ to more than $11 \%$ for each categories over $400 \mathrm{c} / \mathrm{mL}$ (fig 1). The median duration of ART during pregnancy was significantly shorter in mothers of infected than non infected children (9.5 versus 16 weeks globally, $\mathrm{p}<0.001 ; 11$ versus 16 weeks in term births, $\mathrm{p}=0.001 ; 5$ versus 17 weeks in premature births, $\mathrm{p}=0.002$ ). The relationship between transmission rate and ART duration was significantly non linear in the whole population $(\mathrm{p}=0.003)$, with a strong decreasing transmission rate between 0 and 12 duration weeks, more slightly beyond 12 weeks (fig 2). Excluding premature births, only the linear term was significant, overall $(\mathrm{p}=0.003)$, as well as in the subgroup of mothers who delivered with viral load below $400 \mathrm{c} / \mathrm{mL}(\mathrm{p}=0.02)$.

MTCT was also associated with the time at booking visit to the obstetrical center $(\mathrm{p}=0.001)$, the lack of intrapartum prophylaxis $(\mathrm{p}=0.025)$, sub-Saharan African origin $(\mathrm{p}=0.009)$ and child gender ( $\mathrm{p}=0.022$ ). The higher rate of infection in female than male neonates was not due to a difference in perinatal mortality in males $(24 / 2708 ; 0.7 \%)$ vs females $(17 / 2569 ; 0.9 \%, \mathrm{p}=0.4)$, or in proportion with missing HIV status. Neither maternal age, parity, mode of delivery ( $\mathrm{p}=0.13$ ), knowledge of HIV status before pregnancy, type of maternal ART, nor the type of postnatal prophylaxis were associated with MTCT. 
Severe prematurity, HIV RNA level, global duration of ART, and child gender remained independently associated with MTCT in the final model of the stepwise logistic regression (Table 3). The adjusted odds ratio (ORa) for severe prematurity versus term delivery was 3.37 (95\%CI: 1.40-8.11) ; however, it was not significantly different from one in mothers who delivered below 400 copies/mL (2.30; 95\%CI: 0.29-18.48) whereas it passed to 4.60 (95\%CI, 1.78-11.84) beyond 400 copies/mL. Elective cesarean section, not significantly associated with transmission in the initial model, became significantly linked to a lower risk of transmission in the final model.

\section{Risk factors of MTCT in term births with virological failure}

In the 364 women who term delivered with viral load $\geq 10000$ copies $/ \mathrm{mL}$, the MTCT rate was: $6.6 \%$ (95\%CI, 4.3 - 9.7\%). Intrapartum prophylaxis was strongly associated with a lower risk of transmission: $5.3 \%(18 / 339)$ vs $22.7 \%(5 / 22)$ without intrapartum prophylaxis $(\mathrm{p}=0.009)$ (Table 2). Mothers who booked in the first trimester had a lower transmission risk (1.9\%) than those booking in the second $(9.9 \%)$ or third trimester $(10.9 \%)(\mathrm{p}=0.03)$. These two factors remained associated with MTCT after adjustment in both initial and final stepwise logistic regression models (Table 3). The adjusted OR associated with no intrapartum therapy was: 4.72 (95\%CI, 1.42-15.71; $\mathrm{p}=0.011)$.

\section{Risk factors of MTCT in term births with virological success}

In the 2856 mothers who term delivered with viral load below 400 copies $/ \mathrm{mL}$, the MTCT rate was $0.6 \%(95 \% \mathrm{CI}, 0.3-1.0 \%)$. The rate was as low as $0.4 \%(5 / 1338 ; 95 \% \mathrm{CI}, 0.1-0.9)$ in women who delivered with viral load below $50 \mathrm{c} / \mathrm{mL}$. Global duration of ART was the only significant risk factor which remained in the initial and final models issued from stepwise logistic regression. The OR for each increment week was: 0.94 (95\%CI, 0.90-0.99; $\mathrm{p}=0.031$ ). Included in the model instead of global ART duration, time at initiation of ART or duration of last ART were also correlated with transmission ( $\mathrm{p}=0.011$ and 0.013 respectively). Including children with missing HIV status, as non infected, conducted to similar results. Among the more 
homogenous subgroup of 780 women who booked at first trimester and received HAART, the transmission rate was: $0 / 392$ for women already treated at the onset of pregnancy, $1.0 \%(2 / 192)$ when ART was started in the first trimester, $0.9 \%(1 / 113)$ in the second trimester, and $3.6 \%$ (3/83) in the third trimester $(p=0.006)$. It is of interest to note that the five mothers who transmitted despite viral loads below $50 \mathrm{c} / \mathrm{mL}$ started therapy relatively late, between 32 and 33 weeks. Among the infected children term born to mothers having less than $400 \mathrm{c} / \mathrm{mL}$ at delivery, 43\% had a positive HIV1 PCR in the first 3 days, suggesting in utero transmission. This proportion was $21 \%$ at $10000 \mathrm{c} / \mathrm{ml}$ or more (fig 1 ).

\section{Discussion}

The objective of this study, the largest to date of HIV-1 mother-to-child transmission in the HAART era, was to identify risk factors for persistent cases of transmission despite the use of antiretroviral therapy during pregnancy. During the period 1997-2004, the rate of HIV-1 transmission from mothers receiving any antiretroviral therapy during the pregnancy was $1.3 \%$ (95\% CI: 1.0 -1.6). Similar rates are reported during the same period in other studies from industrialized countries $[2,4,26]$. Three main factors were independently related to transmission: high maternal plasma viral load near delivery, short duration of antenatal antiretroviral therapy and very premature delivery. We also found an independent association with gender as previously reported $[27,28,29]$.

Maternal viral load clearly stands out as the key determinant of mother-to-child transmission risk, as has been consistently reported in all studies [2, 6, 30-37]. In term births, the MTCT rate was 10 times higher when last maternal plasma HIV1 RNA was above rather than below 10,000 $\mathrm{c} / \mathrm{mL}(7.2 \%$ vs $0.8 \%, \mathrm{p}<0.01)$. The rate was $0.5 \%$ below $400 \mathrm{c} / \mathrm{mL}$ and as low as $0.4 \%$ below 50 $\mathrm{c} / \mathrm{mL}$.

In French guidelines issued in the study period, zidovudine monotherapy was restricted to women who did not require therapy for their own health and had pre-therapeutic plasma viral loads below 10000 copies/mL [38]. Thus monotherapy was indicated in women at lower risk of 
transmitting the virus, which was likely to explain that MTCT rate did not differ according to the antiretroviral regimen. Be that as it may, our data confirmed that good control of maternal viral load is a key method to prevent MTCT, whatever the type of antiretroviral strategy used to obtain it.

Maternal viral load above $10000 \mathrm{c} / \mathrm{mL}$ at term delivery should not occur according to accepted guidelines [6, 38]. This situation concerned less than $10 \%$ of mothers, but contributed to half of the infected children. It occurred even though 45\% delivered with HAART and 27\% with dualdrug therapy, and may be due to poor adherence, multidrug resistance or treatment interruptions related to poor tolerance, or late access to adequate prenatal care, significantly associated with transmission. Intrapartum prophylaxis appeared to have a strong protective effect in case of virological failure. In contrast, among women with viral loads below 10000 copies/ml, there was no case of transmission among the 125 women who did not receive intrapartum prophylaxis.

MTCT rate was inversely related to duration of antenatal therapy. Relation with very short zidovudine monotherapy was previously demonstrated in Thailand [8]. The non linear increasing risk in our survey reflected the high rate of transmission in very premature births with low duration: poorer control of HIV viral load due to an unexpectedly short time between the start of maternal therapy and delivery may partly explain the association between transmission and severe prematurity. Overall, the rate was 6-fold higher when deliveries occurred before 33 weeks than at 37 weeks or more. Two results suggest that other factors, not collected in EPF during the study period, may increase perinatal exposure to HIV in severely preterm delivery, such as preterm premature rupture of the membranes, abruption, and chorioamnionitis: the association remained significant after adjusting for duration of ART, maternal plasma viral load, mode of delivery and intrapartum prophylaxis ; the transmission rate was not increased in case of moderately premature deliveries. 
In term births, the increasing risk of transmission with duration of therapy seemed more related to a very low transmission in women who were receiving ART since the first weeks of pregnancy. The time needed to achieve undetectable HIV RNA by the time of delivery may partly account for this finding, as it is generally obtained in non pregnant adults by 10 to 16 weeks [39]. In addition, in utero transmission may occur before therapy is initiated or effective. Presumed in utero transmission occurred in near one half of the children term born with maternal HIV1 RNA level below 400 copies/mL.

Elective cesarean section tended to be associated with a lower risk of MTCT in the overall population. However we observed no significant difference in transmission risk according to the mode of delivery among women who delivered with viral load below $400 \mathrm{c} / \mathrm{mL}$ (crude OR: 0.83; 0.29-2.39; $\mathrm{p}=0.37$ ). A protective effect of elective cesarean section was established in our cohort $[16]$ and others $[17,18]$, in the absence of antiretroviral prevention and in a period when standard care was zidovudine monotherapy. It is unclear whether such a protective effect persists in women receiving ART with low viral load at delivery. Data from the PACTG [26, 40] failed to show a difference in transmission rate according to mode of delivery in treated women with low viral loads. A recent study reported an association between the mode of delivery and mother-to-child HIV-1 transmission risk, although the association was not statistically significant in the subgroup of women receiving antenatal HAART [4]. In our study, women who received HAART and delivered with viral load below $400 \mathrm{c} / \mathrm{mL}$ had a transmission rate of $0.4 \%(3 / 747)$ with elective caesarean and $0.5 \%$ (3/574) with vaginal delivery $(\mathrm{p}=0.35)$. But the power to show a 2 -fold decrease was only $18 \%$. The potential benefit of systematic cesarean delivery would have to be balanced with the risks, in a scenario where at least several hundred operations would be required to avoid one case of transmission [11, 41].

The methods available today are able to reduce mother-to-child HIV transmission to well below one percent. Our data confirm the major impact of achieving an undetectable maternal plasma viral load, with only $0.4 \%$ transmission among term-born children whose mothers had viral 
loads below $50 \mathrm{c} / \mathrm{mL}$ at delivery. The most consistent means available to obtain such a control of viral replication is the use of triple combination therapy. Furthermore, our findings strongly suggest that antiretroviral therapy should be started relatively early, at the latest by 28 weeks, to obtain maximum efficacy. However, any incremental benefit of more aggressive and/or longer antiretroviral exposure has to be evaluated against the risks of toxicities, such as adverse events during pregnancy, prematurity, neonatal malformations or mitochondrial dysfunctions in uninfected infants $[11,42,43]$. The key challenge is to improve early access to specific care and treatment as well as adherence in pregnant women in order to achieve viral suppression during the last trimester of the pregnancy. 
1. Connor EM, Sperling RS, Gelber R, Kiselev P, Scott G, O'Sullivan MJ, et al. Reduction of maternal-infant transmission of human immunodeficiency virus type 1 with zidovudine treatment. Pediatric AIDS Clinical Trials Group Protocol 076 Study Group. $N$ Engl $\mathrm{J}$ Med 1994,331:1173-1180.

2. Cooper ER, Charurat M, Mofenson L, Hanson IC, Pitt J, Diaz C, et al. Combination antiretroviral strategies for the treatment of pregnant HIV-1-infected women and prevention of perinatal HIV-1 transmission. J Acquir Immune Defic Syndr 2002,29:484-494.

3. Mandelbrot L, Landreau-Mascaro A, Rekacewicz C, Berrebi A, Benifla JL, Burgard M, et al. Lamivudine-zidovudine combination for prevention of maternal-infant transmission of HIV-1. JAMA 2001,285:2083-2093.

4. European Collaborative Study. Mother-to-child transmission of HIV infection in the era of highly active antiretroviral therapy. Clin Infect Dis 2005,40:458-465.

5. Ioannidis JP, Abrams EJ, Ammann A, Bulterys M, Goedert JJ, Gray L, et al. Perinatal transmission of human immunodeficiency virus type 1 by pregnant women with RNA virus loads < $\mathbf{1 0 0 0}$ copies/ml. $J$ Infect Dis 2001,183:539-545.

6. Recommendations PHSTF. Use of Antiretroviral Drugs in Pregnant HIV-1-Infected Women for Maternal Health and Interventions to Reduce Perinatal HIV-1 Transmission in the United States. In: http://aidsinfo.nih.gov/; 2005.

7. Delfraissy JF. Prise en charge thérapeutique des personnes infectées par le VIH. Recommandations du groupe d'expert. Paris: Flammarion Médecine Sciences/ http://www.sante.gouv.fr; 2004.

8. Lallemant M, Jourdain G, Le Coeur S, Kim S, Koetsawang S, Comeau AM, et al. A trial of shortened zidovudine regimens to prevent mother-to-child transmission of human immunodeficiency virus type 1. Perinatal HIV Prevention Trial (Thailand) Investigators. $N$ Engl J Med 2000,343:982-991.

9. Wade NA, Birkhead GS, Warren BL, Charbonneau TT, French PT, Wang L, et al. Abbreviated regimens of zidovudine prophylaxis and perinatal transmission of the human immunodeficiency virus. $N$ Engl $J$ Med 1998,339:1409-1414.

10. Mofenson LM, Munderi P. Safety of antiretroviral prophylaxis of perinatal transmission for HIV-infected pregnant women and their infants. J Acquir Immune Defic Syndr 2002,30:200-215.

11. Watts DH, Balasubramanian R, Maupin RT, Jr., Delke I, Dorenbaum A, Fiore S, et al. Maternal toxicity and pregnancy complications in human immunodeficiency virus-infected women receiving antiretroviral therapy: PACTG 316. Am J Obstet Gynecol 2004,190:506-516.

12. The European Collaborative Study, the Swiss Mother Child HIV Cohort Study Combination antiretroviral therapy and duration of pregnancy. AIDS 2000,14:2913-2920.

13. Lyons FE, Coughlan S, Byrne CM, Hopkins SM, Hall WW, Mulcahy FM. Emergence of antiretroviral resistance in $\mathrm{HIV}$-positive women receiving combination antiretroviral therapy in pregnancy. AIDS 2005,19:63-67.

14. Stratton P, Tuomala RE, Abboud R, Rodriguez E, Rich K, Pitt J, et al. Obstetric and newborn outcomes in a cohort of $\mathrm{HIV}$-infected pregnant women: a report of the women and infants transmission study. J Acquir Immune Defic Syndr Hum Retrovirol 1999,20:179-186.

15. Mandelbrot L, Mayaux MJ, Bongain A, Berrebi A, Moudoub-Jeanpetit Y, Benifla JL, et al. Obstetric factors and mother-to-child transmission of human immunodeficiency virus type 1: the French perinatal cohorts. SEROGEST French Pediatric HIV Infection Study Group. Am J Obstet Gynecol 1996,175:661-667.

16. Mandelbrot L, Le Chenadec J, Berrebi A, Bongain A, Benifla JL, Delfraissy JF, et al. Perinatal HIV-1 transmission: interaction between zidovudine prophylaxis and mode of delivery in the French Perinatal Cohort. JAMA 1998,280:55-60. 
17. The European Mode of Delivery Collaboration. Elective caesarean-section versus vaginal delivery in prevention of vertical HIV-1 transmission: a randomised clinical trial. . Lancet 1999,353:1035-1039.

18. The International Perinatal HIV Group. The mode of delivery and the risk of vertical transmission of human immunodeficiency virus type 1--a meta-analysis of 15 prospective cohort studies. $N$ Engl $J$ Med 1999,340:977-987.

19. Mayaux MJ, Blanche S, Rouzioux C, Le Chenadec J, Chambrin V, Firtion G, et al. Maternal factors associated with perinatal HIV-1 transmission: the French Cohort Study: 7 years of follow-up observation. The French Pediatric HIV Infection Study Group. J Acquir Immune Defic Syndr Hum Retrovirol 1995,8:188-194.

20. Burgard M, Izopet J, Dumon B, Tamalet C, Descamps D, Ruffault A, et al. HIV RNA and HIV DNA in peripheral blood mononuclear cells are consistent markers for estimating viral load in patients undergoing long-term potent treatment. AIDS Res Hum Retroviruses 2000,16:19391947.

21. Viard JP, Burgard M, Hubert JB, Aaron L, Rabian C, Pertuiset N, et al. Impact of 5 years of maximally successful highly active antiretroviral therapy on CD4 cell count and HIV-1 DNA level. AIDS 2004,18:45-49.

22. Burgard M, Mayaux MJ, Blanche S, Ferroni A, Guihard-Moscato ML, Allemon MC, et al. The use of viral culture and p24 antigen testing to diagnose human immunodeficiency virus infection in neonates. The HIV Infection in Newborns French Collaborative Study Group. $N$ Engl $J$ Med 1992,327:1192-1197.

23. S-Plus. Guide to Statistic, Volume 1. Seattle, WA: Data Analysis Products Division; 2000.

24. Hastie T, Tibshirani R. Generalized additive models. London: Chapman \& Hall; 1995.

25. StataCorp. Stata Statistical Software: Release 8.0. College Station, TX: Stata Corporation; 2003.

26. Dorenbaum A, Cunningham CK, Gelber RD, Culnane M, Mofenson L, Britto P, et al. Two-dose intrapartum/newborn nevirapine and standard antiretroviral therapy to reduce perinatal HIV transmission: a randomized trial. JAMA 2002,288:189-198.

27. Taha TE, Nour S, Kumwenda NI, Broadhead RL, Fiscus SA, Kafulafula G, et al. Gender differences in perinatal HIV acquisition among African infants. Pediatrics 2005,115:e167-172.

28. Galli L, Puliti D, Chiappini E, Gabiano C, Tovo PA, Pezzotti P, de Martino M. Lower mother-tochild HIV-1 transmission in boys is independent of type of delivery and antiretroviral prophylaxis: the Italian Register for HIV Infection in Children. J Acquir Immune Defic Syndr 2005,40:479-485.

29. Thorne C, Newell ML. Are girls more at risk of intrauterine-acquired HIV infection than boys? AIDS 2004,18:344-347.

30. Mayaux MJ, Dussaix E, Isopet J, Rekacewicz C, Mandelbrot L, Ciraru-Vigneron N, et al. Maternal virus load during pregnancy and mother-to-child transmission of human immunodeficiency virus type 1: the French perinatal cohort studies. SEROGEST Cohort Group. J Infect Dis 1997,175:172-175.

31. Sperling RS, Shapiro DE, Coombs RW, Todd JA, Herman SA, McSherry GD, et al. Maternal viral load, zidovudine treatment, and the risk of transmission of human immunodeficiency virus type 1 from mother to infant. Pediatric AIDS Clinical Trials Group Protocol 076 Study Group. N Engl J Med 1996,335:1621-1629.

32. Lallemant M, Jourdain G, Le Coeur S, Mary JY, Ngo-Giang-Huong N, Koetsawang S, et al. Singledose perinatal nevirapine plus standard zidovudine to prevent mother-to-child transmission of HIV-1 in Thailand. $N$ Engl $J$ Med 2004,351:217-228.

33. Cao Y, Krogstad P, Korber BT, Koup RA, Muldoon M, Macken C, et al. Maternal HIV-1 viral load and vertical transmission of infection: the Ariel Project for the prevention of HIV transmission from mother to infant. Nat Med 1997,3:549-552.

34. Dickover RE, Garratty EM, Herman SA, Sim MS, Plaeger S, Boyer PJ, et al. Identification of levels of maternal HIV-1 RNA associated with risk of perinatal transmission. Effect of maternal zidovudine treatment on viral load. JAMA 1996,275:599-605. 
35. Garcia PM, Kalish LA, Pitt J, Minkoff H, Quinn TC, Burchett SK, et al. Maternal levels of plasma human immunodeficiency virus type 1 RNA and the risk of perinatal transmission. Women and Infants Transmission Study Group. $N$ Engl J Med 1999,341:394-402.

36. The European Collaborative Study. Maternal viral load and vertical transmission of HIV-1: an important factor but not the only one AIDS 1999,13:1377-1385.

37. Mofenson LM, Lambert JS, Stiehm ER, Bethel J, Meyer WA, 3rd, Whitehouse J, et al. Risk factors for perinatal transmission of human immunodeficiency virus type 1 in women treated with zidovudine. Pediatric AIDS Clinical Trials Group Study 185 Team. $N$ Engl J Med 1999,341:385-393.

38. Delfraissy JF. Prise en charge thérapeutique des personnes infectées par le VIH. Recommandations du groupe d'expert. Paris: Flammarion Médecine Sciences/ http://www.sante.gouv.fr; 2002.

39. Walmsley S, Bernstein B, King M, Arribas J, Beall G, Ruane P, et al. Lopinavir-ritonavir versus nelfinavir for the initial treatment of HIV infection. $N$ Engl J Med 2002,346:2039-2046.

40. D Shapiro R, Tuomala H, Pollack S, Burchett J, Read M, Cababasay J, et al. Mother-to-child HIV transmission risk according to antiretroviral therapy, mode of delivery, an viral load in 2895 U.S. women (PACTG367). The 11th Conference on Retroviruses and Opportunistics Infections. San Francisco 2004.

41. Marcollet A, Goffinet F, Firtion G, Pannier E, Le Bret T, Brival ML, Mandelbrot L. Differences in postpartum morbidity in women who are infected with the human immunodeficiency virus after elective cesarean delivery, emergency cesarean delivery, or vaginal delivery. Am J Obstet Gynecol 2002,186:784-789.

42. Barret B, Tardieu M, Rustin P, Lacroix C, Chabrol B, Desguerre I, et al. Persistent mitochondrial dysfunction in HIV-1-exposed but uninfected infants: clinical screening in a large prospective cohort. AIDS 2003,17:1769-1785.

43. Tuomala RE, Shapiro DE, Mofenson LM, Bryson Y, Culnane M, Hughes MD, et al. Antiretroviral therapy during pregnancy and the risk of an adverse outcome. $N$ Engl $J$ Med 2002,346:18631870. 


\section{Acknowledgments}

This study was supported by the French National Agency for AIDS Research (ANRS), Paris, France. We thank Valerie Benhammou, Karima Hamrene, Yassine Benmebarek, Corinne Laurent, Elisa Ramos, Marlène Peres.

The persons and institutions who participated in the ANRS French Perinatal Cohort (EPF) are listed in the annexe.

Josiane Warszawski declare to be independent of any commercial funder, to have performed the statistical analysis and have full access to all the data in the study and take responsibility for the integrity of the data and the accuracy of the data analysis. 


\section{APPENDIX}

The following persons and institutions participated in the ANRS French Perinatal Cohort (EPF):

Hôpital d'Aix en Provence* (Tadrist B.); Hôpital Nord, Amiens (Schmit J.L., Horlé B.); Hôpital d'Angers (Fournié A.); Hôpital Victor Dupouy, Argenteuil (Brault D.); Hôpital Paris La Roseraie*, Aubervilliers (Rozan M.A.); Hôpital Robert Ballanger, Aulnay (Zakaria A.); Hôpital Saint Claude, Basse-Terre* (Sibille G.); Hôpital de Bastia (Pincemaille O.); Hôpital de la Côte Basque, Bayonne (Cayla C.); Clinique du Blanc Mesnil* (Balde P.); Hôpital Saint Jacques, Besançon (Estavoyer J.M.); Hôpital Avicenne, Bobigny (Bentata M.); Hôpital Jean Verdier, Bondy (Lachassine E., Rodrigues A.); Hôpital Pellegrin, Bordeaux (Roux D., Douard D.); Hôpital Ambroise Paré*, Boulogne Billancourt (Zenaty D.); Hôpital Clémenceau, Caen (Brouard J.); Hôpital André Rosemon, Cayenne (Elenga N.); Hôpital Beaujon*, Clichy (De Curtis A.); Hôpital de Creil (Kingue-Ekollo C.); Hôpital Intercommunal, Créteil (Garrait V., Lemerle S., Pichon C.); Hôpital Béclère, Clamart (Chambrin V., Labrune P., Clech L.); Hôpital Louis Mourier, Colombes (CrennHebert C., Floch-Tudal C.); Hôpital de Compiègne* (Lagrue A.); Hôpital d'enfants, Dijon (Reynaud I.; Martha S.); Hôpital de Dourdan* (Ercoli V.); Hôpital de Dreux* (Denavit M.F.); Hôpital des Feugrais*, Elbeuf (Lahsinat K.); Hôpital Intercommunal, Evreux (Touré K.); Hôpital Francilien Sud, Evry-Corbeil (Devidas A., May A., Granier M.); Hôpital de Fontainebleau (Routier C.); Hôpital Victor Fouche, Fort de France (Hatchuel Y.); Hôpital de Gonesse* (Balde P.); Hôpital Jean Rostand, Ivry (Jault T.); Hôpital de Lagny (Chalvon Demersay A.); Hôpital du Lamentin* (Monlouis M.); Hôpital Les Oudairies, La Roche sur Yon (Perré P); Hôpital de La Seyne sur Mer (Chamouilli J.M.); Hôpital Louis Domergue, La Trinité* (Hugon N.); Hôpital André Mignot, Le Chesnay (Hentgen V., Messaoudi F.); Hôpital de Bicêtre, Le Kremlin-Bicêtre (Peretti D., Fridman S); Hôpital Jeanne de Flandres, Lille (Mazingue F., Hammou Y.); Hôpital Dupuytren*, Limoges (De lumley L.); Hôpital de Longjumeau (Seaume H.); Hôpital Hôtel DieuHôpital Debrousse, Lyon (Cotte L., Kebaïli K.); Hôpital François Quesnay, Mantes La Jolie (Doumet A.); Hôpital la Conception, Marseille (Cravello L., Thuret I.); Hôpital de Meaux (Karaoui L.); Hôpital de Meulan* (Seguy D.); Hôpital Marc Jacquet, Melun (Le Lorier B.); Hôpital Intercommunal, Montfermeil (Talon P.); Hôpital Arnaud de Villeneuve, Montpellier (Benos P., Lalande M.); Hôpital Intercommunal, Montreuil (Heller-Roussin B.); Maternité Régionale A. Pinard, Nancy (Hubert C.); Hôpital de Nanterre* (Karoubi P.); Hôpital de Nantes (Reliquet, V., Brunet-François C.); Hôpital de Neuilly sur Seine* (Berterottiere D.); Hôpital l’Archet-Fondation Lenval, Nice (Monpoux F., Bongain A., Deville A.); Hôpital Caremeau, Nîmes (Dendale J.); Hôpital Orléans (Arsac P.); Hôpital d’Orsay (De Gennes C.); Hôpital Bichat, Paris (Matheron S., Batallan A.); Hôpital Boucicaut*, Paris (Lafay Pillet M.C.); Hôpital CochinPort Royal, Paris (Firtion G., Pannier A); Hôpital Lariboisière, Paris (Ciraru-Vigneron N.); Hôpital des Métallurgistes*, Paris (Rami M.); Institut Mutualiste Montsouris*, Paris (Carlus Moncomble C.); Hôpital Necker, Paris (Parat S., Blanche S., Rouzioux C.); Hôpital Notre Dame du Bon Secours, Paris (Ayral D.); Hôpital Pitié Salpêtrière, Paris (Tubiana R.); Hôpital Robert Debré, Paris (Levine M., Faye A., Ottenwalter A.); Hôpital Rothschild, Paris (Wallet A.); Hôpital Saint-Antoine, Paris (Carbonne B.); Hôpital Hôpital Saint Michel, Paris (Aufrant C.); Hôpital Tenon, Paris (Lebrette M.G.); Hôpital Trousseau, Paris (Dollfus C.); Hôpital Marechal Joffre, Perpignan (Medus M.); Hôpital Les Abymes, Pointe-à-Pitre (Bataille H.); Hôpital de Poissy-Saint-Germain en Laye* (Rousset M.C.); Hôpital René Dubos, Pontoise (Mouchnino G.); Hôpital Américain, Reims (Munzer M.); Hôpital Charles Nicolle, Rouen (Brossard V.); Hôpital de SaintDenis (Allemon M.C., Ekoukou D., Khuong M.A.); Hôpital Nord, Saint Etienne (Billiemaz K.); Hôpital de Saint Martin (Bissuel F.); Hôpital Esquirol*, Saint-Maurice (Robin M.); Hôpital de Sèvres* (Segard L.); Hôpital de Haute Pierre-Hôpital Civil, Strasbourg (Partisani M., Favreau, J. J, Entz-Werle N.); C.M.C. Foch, Suresnes* (Botto C.); Hôpital Chalucet,Toulon (Hittinger G.); Hôpital La Grave, Toulouse (Berrebi A., Tricoire J.); Hôpital Bretonneau, Tours (Besnier J.M.); Hôpital Brabois, Vandoeuvre les Nancy (Neimann L.); Hôpital Paul Brousse*,Villejuif (Dussaix E.); Hôpital de Villeneuve Saint Georges (Guillot F., Chacé A.). 


\section{Legends of figures}

Fig 1 - MTCT rates according to HIV RNA level at delivery - The ANRS French Perinatal Cohort (19972004)

Estimations were based on 5074 available data among the 5271 included mother-child pairs who received antenatal ART and did not breastfed

HIV-1 PCR in the first 3 days was not available for 12 among 52 term born infected neonates and 7 among 15 premature infected neonates

Fig 2 - Relationship between duration of ART during pregnancy and MTCT rate. The ANRS French Perinatal Cohort (1997-2004)

The curve was estimated by a generalized additive model (GAM) with a non linear term (splines). The model was based on 5235 available data among the 5271 included mother-child pairs who received antenatal therapy and did not breastfed.

Plain line: all births ( $\mathrm{N}=5$ 235)

Dotted line: term births (37 weeks or more) $(\mathrm{N}=4554)$.

Bold dotted line : term births (37 weeks or more) and maternal HIV-1 RNA $<400 \mathrm{c} / \mathrm{mL} \quad(\mathrm{N}=2840)$. 
Table 1 - Characteristics of HIV-1 mother-child pairs according to maternal HIV RNA level at delivery 1997$2004^{\dagger}$ - The ANRS French Perinatal Cohort

\begin{tabular}{|c|c|c|c|c|c|c|c|c|}
\hline & \multirow{2}{*}{\multicolumn{2}{|c|}{ Total }} & \multicolumn{6}{|c|}{ Maternal HIV-1 RNA at delivery, copies/mL } \\
\hline & & & \multicolumn{2}{|c|}{$<400$} & \multicolumn{2}{|c|}{$400-9999$} & \multicolumn{2}{|c|}{$\geq 10000$} \\
\hline & $\mathrm{N}$ & $\%$ & $\mathrm{~N}$ & $\%$ & $\mathrm{~N}$ & $\%$ & $\mathrm{~N}$ & $\%$ \\
\hline \multicolumn{9}{|l|}{ Year of delivery } \\
\hline $1997-98$ & 1024 & 19.4 & 510 & 15.7 & 361 & 26.2 & 93 & 21.1 \\
\hline $1999-00$ & 1293 & 24.5 & 660 & 20.3 & 438 & 31.8 & 161 & 36.6 \\
\hline 2001-02 & 1549 & 29.4 & 1030 & 31.6 & 348 & 25.3 & 122 & 37.7 \\
\hline 2003-04 & 1405 & 26.7 & 1056 & 32.4 & 231 & 16.8 & 64 & 14.6 \\
\hline \multicolumn{9}{|l|}{ Active drug use } \\
\hline Yes & 144 & 2.7 & 68 & 2.1 & 50 & 3.6 & 21 & 4.8 \\
\hline \multicolumn{9}{|l|}{ Geographical origin } \\
\hline Sub-Saharan Africa & 2935 & 55.9 & 1845 & 56.8 & 734 & 53.6 & 244 & 55.6 \\
\hline \multicolumn{9}{|l|}{ Gestational age at booking, wk } \\
\hline 3rd trimester $(\geq 28)$ & 536 & 10.4 & 270 & 8.5 & 167 & 12.7 & 66 & 15.4 \\
\hline 2nd trimester (14-27) & 2165 & 42.0 & 1323 & 41.5 & 583 & 43.2 & 177 & 41.4 \\
\hline 1st trimester $(<14)$ & 2450 & 47.6 & 1592 & 50.0 & 600 & 44.4 & 185 & 43.2 \\
\hline \multicolumn{9}{|l|}{ Gestational age at delivery, wk } \\
\hline$<33$ & 122 & 2.3 & 60 & 1.8 & 30 & 2.2 & 24 & 5.5 \\
\hline $33-36$ & 563 & 10.7 & 339 & 10.4 & 147 & 10.7 & 52 & 11.8 \\
\hline$\geq 37$ & 4583 & 87.0 & 2856 & 87.7 & 1201 & 87.2 & 364 & 82.7 \\
\hline \multicolumn{9}{|l|}{ Maternal CD4 cell count at delivery } \\
\hline$<200$ cells $/ \mathrm{mm}^{3}$ & 520 & 10.2 & 269 & 8.4 & 139 & 10.2 & 104 & 24.2 \\
\hline $200-349$ & 1134 & 22.2 & 655 & 20.4 & 319 & 23.5 & 130 & 30.2 \\
\hline$\geq 350$ & 3459 & 67.7 & 2284 & 71.2 & 899 & 66.3 & 196 & 45.6 \\
\hline \multicolumn{9}{|l|}{ Gender of neonate } \\
\hline Male & 2684 & 51.3 & 1604 & 49.7 & 754 & 54.9 & 214 & 49.0 \\
\hline \multicolumn{9}{|l|}{ Mode of delivery } \\
\hline Elective Caesarean & 2438 & 46.5 & 1409 & 43.5 & 719 & 52.4 & 230 & 52.6 \\
\hline Emergency Caesarean & 1046 & 20.0 & 633 & 19.5 & 256 & 18.7 & 117 & 26.8 \\
\hline Vaginal delivery & 1758 & 33.5 & 1201 & 37.0 & 396 & 28.9 & 90 & 20.6 \\
\hline Initiation of antenatal ART, median wk (IQ) & \multicolumn{2}{|c|}{$22(0-29)$} & \multicolumn{2}{|c|}{$21(0-28)$} & \multicolumn{2}{|c|}{$24(12-30)$} & \multicolumn{2}{|c|}{$23(9-29)$} \\
\hline Duration of antenatal ART, median wk (IQ) & \multicolumn{2}{|c|}{$16(9-33)$} & \multicolumn{2}{|c|}{$17(10-35)$} & \multicolumn{2}{|c|}{$14(8-26)$} & \multicolumn{2}{|c|}{$14(8-29)$} \\
\hline \multicolumn{9}{|l|}{ Last antenatal ART } \\
\hline HAART & 2513 & 47.8 & 1842 & 56.7 & 391 & 28.4 & 196 & 44.6 \\
\hline Dual-drug therapy & 1745 & 33.2 & 1045 & 32.1 & 526 & 38.3 & 119 & 27.1 \\
\hline Monotherapy & 1003 & 19.1 & 364 & 11.2 & 458 & 33.3 & 125 & 28.4 \\
\hline \multicolumn{9}{|l|}{ Intrapartum prophylaxis } \\
\hline Yes & 5006 & 95.6 & 3120 & 96.2 & 1300 & 95.0 & 407 & 95.6 \\
\hline Postnatal child prophylaxis & & & & & & & & \\
\hline Dual or HAART & 1204 & 23.0 & 651 & 20.2 & 396 & 28.9 & 122 & 28.0 \\
\hline Monotherapy & 3990 & 76.3 & 2551 & 79.0 & 966 & 70.5 & 314 & 72.0 \\
\hline None or late & 37 & 0.7 & 28 & 1.0 & 8 & 0.6 & 0 & 0 \\
\hline
\end{tabular}

† Eligible population: HIV-1 infected women who delivered between January 1, 1997 and December 31, 2004, and : (1) received at least one antenatal ART at any time during pregnancy, (2) did not breastfeed and (3) with child's infection status documented.

$\mathrm{IQ}=$ interquartile range

ART=antiretroviral therapy, HAART=highly active antiretroviral therapy. 
Table 2 - Mother-to-child transmission (MTCT) in women receiving antiretroviral therapy during the pregnancy univariate analysis - The ANRS French Perinatal Cohort (1997-2004)

\begin{tabular}{|c|c|c|c|c|c|c|c|c|c|c|c|c|}
\hline & \multirow{2}{*}{\multicolumn{4}{|c|}{ All births }} & \multicolumn{8}{|c|}{ Term births } \\
\hline & & & & & \multicolumn{4}{|c|}{$\begin{array}{l}\text { Maternal HIV-1 RNA at } \\
\text { delivery }<400 \mathrm{cp} / \mathrm{mL}\end{array}$} & \multicolumn{4}{|c|}{$\begin{array}{l}\text { Maternal HIV-1 RNA at } \\
\text { delivery > } 10000 \mathrm{cp} / \mathrm{mL}\end{array}$} \\
\hline & $\mathrm{N}^{\dagger}$ & $\mathrm{n}^{\dagger}$ & $\%$ & $\mathrm{p}^{\#}$ & $\mathrm{~N}^{\dagger}$ & $\mathrm{n}^{\dagger}$ & $\%$ & $\mathrm{p}^{\#}$ & $\mathrm{~N}^{\dagger}$ & $\mathrm{n}^{\dagger}$ & $\%$ & $\mathrm{p}^{\#}$ \\
\hline Total & 5271 & 67 & 1.3 & & 2856 & 17 & 0.6 & & 364 & 24 & 6.6 & \\
\hline \multicolumn{13}{|l|}{ Gestational age at delivery, wk } \\
\hline$<33$ week & 122 & 8 & 6.6 & $<0.001$ & & & & & & & & \\
\hline $33-36$ & 563 & 7 & 1.2 & & & & & & & & & \\
\hline$\geq 37$ & 4583 & 52 & 1.1 & & & & & & & & & \\
\hline \multicolumn{13}{|l|}{ Maternal HIV-1 RNA at delivery } \\
\hline$\geq 10000 \quad$ copies $/ \mathrm{mL}$ & 440 & 30 & 6.8 & $<0.001$ & & & & & & & & \\
\hline 1000-9999 & 938 & 14 & 1.5 & & & & & & & & & \\
\hline 400-999 & 440 & 3 & 0.7 & & & & & & & & & \\
\hline$<400$ & 3256 & 19 & 0.6 & & & & & & & & & \\
\hline \multicolumn{13}{|l|}{ Active drug use } \\
\hline Yes & 144 & 2 & 1.4 & 0.71 & 49 & 0 & 0 & 1.00 & 20 & 2 & 10.0 & 0.63 \\
\hline No & 5125 & 65 & 1.3 & & 2806 & 17 & 0.6 & & 344 & 22 & 6.4 & \\
\hline \multicolumn{13}{|l|}{ Geographical origin } \\
\hline Sub-Saharan Africa & 2935 & 48 & 1.6 & 0.009 & 1642 & 12 & 0.7 & 0.28 & 199 & 17 & 8.5 & 0.103 \\
\hline Other origin & 2318 & 19 & 0.8 & & 1208 & 5 & 0.4 & & 164 & 7 & 4.3 & \\
\hline \multicolumn{13}{|l|}{ Gestational age at booking, wk } \\
\hline 3rd trimester ( $\geq 28$ week) & 536 & 15 & 2.8 & 0.001 & 229 & 2 & 0.9 & 0.45 & 55 & 6 & 10.9 & 0.003 \\
\hline 2nd trimester (14-27) & 2165 & 30 & 1.4 & & 1169 & 5 & 0.4 & & 142 & 14 & 9.9 & \\
\hline 1st trimester $(<14)$ & 2450 & 21 & 0.9 & & 1393 & 10 & 0.7 & & 157 & 3 & 1.9 & \\
\hline \multicolumn{13}{|l|}{ Maternal CD4 cell count at delivery } \\
\hline$<200$ cells $/ \mathrm{mm}^{3}$ & 520 & 16 & 3.1 & $<0.001$ & 228 & 3 & 1.3 & 0.19 & 83 & 6 & 7.2 & 0.80 \\
\hline 200-349 & 1134 & 17 & 1.5 & & 572 & 4 & 0.7 & & 110 & 8 & 7.3 & \\
\hline$\geq 350$ & 3459 & 33 & 1.0 & & 2015 & 10 & 0.5 & & 164 & 9 & 5.5 & \\
\hline \multicolumn{13}{|l|}{ Gender of neonate } \\
\hline Female & 2552 & 42 & 1.7 & 0.022 & 1423 & 10 & 0.7 & 0.48 & 185 & 16 & 8.7 & 0.11 \\
\hline Male & 2684 & 25 & 0.9 & & 1411 & 7 & 0.5 & & 177 & 8 & 4.5 & \\
\hline \multicolumn{13}{|l|}{ Mode of delivery } \\
\hline Elective Caesarean & 2438 & 23 & 0.9 & 0.13 & 1296 & 7 & 0.5 & 0.90 & 203 & 10 & 4.9 & 0.37 \\
\hline Emergency Caesarean & 1046 & 18 & 1.7 & & 464 & 3 & 0.7 & & 86 & 8 & 9.3 & \\
\hline Vaginal delivery & 1758 & 25 & 1.4 & & 1083 & 7 & 0.7 & & 72 & 5 & 6.9 & \\
\hline \multicolumn{13}{|l|}{ Initiation of antenatal ART, wk } \\
\hline Non stopped from onset & 1356 & 10 & 0.7 & 0.044 & 759 & 1 & 0.1 & 0.108 & 82 & 6 & 7.3 & 0.96 \\
\hline $4-20$ & 1115 & 10 & 0.9 & & 619 & 3 & 0.5 & & 77 & 4 & 5.2 & \\
\hline $21-28$ & 1117 & 17 & 1.5 & & 606 & 4 & 0.7 & & 71 & 4 & 5.6 & \\
\hline$>28$ & 1647 & 29 & 1.8 & & 856 & 9 & 1.1 & & 132 & 9 & 6.8 & \\
\hline Median infected/non infected & \multicolumn{3}{|c|}{$27 / 22$} & $<0.001$ & \multicolumn{3}{|c|}{29 / 21} & 0.014 & & $25 / 24$ & & 0.46 \\
\hline Duration of antenatal ART, wk & & & & & & & & & & & & \\
\hline Median infected/non infected & & $9.5 / 16$ & & $<0.001$ & & $10 / 17$ & & 0.023 & & $13 / 15$ & & 0.30 \\
\hline Duration of last antenatal ART, w & & & & & & & & & & & & \\
\hline Median infected/non infected & & 7 / 11 & & $<0.001$ & & $8 / 12$ & & 0.013 & & $8 / 10$ & & 0.47 \\
\hline Last antenatal ART & & & & & & & & & & & & \\
\hline HAART & 2513 & 30 & 1.2 & 0.77 & 1585 & 9 & 0.6 & 0.94 & 155 & 13 & 8.4 & 0.48 \\
\hline Dual-drug therapy & 1745 & 22 & 1.3 & & 938 & 6 & 0.6 & & 105 & 6 & 5.7 & \\
\hline Monotherapy & 1003 & 15 & 1.5 & & 328 & 2 & 0.6 & & 104 & 5 & 4.8 & \\
\hline Intrapartum prophylaxis & & & & & & & & & & & & \\
\hline No & 230 & 7 & 3.1 & 0.025 & 95 & 0 & 0 & 1.00 & 22 & 5 & 22.7 & 0.009 \\
\hline Yes & 5006 & 59 & 1.2 & & 2750 & 17 & 0.6 & & 339 & 18 & 5.3 & \\
\hline Postnatal child prophylaxis & & & & & & & & & & & & \\
\hline Dual or HAART & 1159 & 21 & 1.8 & 0.084 & 546 & 3 & 0.6 & 1.00 & 103 & 7 & 6.6 & 0.95 \\
\hline Monotherapy & 3975 & 46 & 1.2 & & 2231 & 14 & 0.6 & & 257 & 17 & 6.8 & \\
\hline None or late & 37 & 0 & 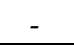 & & & & & & & & & \\
\hline
\end{tabular}

$\dagger \mathrm{n}$ indicates the number of infected children among $\mathrm{N}$ mother-child pairs included in the analysis

\# P-value was obtained by Fisher exact test for active drug use, gestational age, maternal HIV-1 RNA level and intrapartum prophylaxis, by Wilcoxon rank test for ART duration and time at initiation and by Chi-square test for all other variables. ART=antiretroviral therapy, HAART=highly active antiretroviral therapy. 
Table 3 - Mother-to-child transmission (MTCT) in women receiving antiretroviral therapy during the pregnancy - Stepwise logistic regression $\dagger \dagger$ - The ANRS French Prenatal Cohort (1997-2004)

\begin{tabular}{|c|c|c|c|c|c|c|c|c|c|c|c|c|c|c|c|}
\hline & \multirow{2}{*}{\multicolumn{5}{|c|}{$\begin{array}{l}\text { All births } \\
\mathrm{N}=4713 \dagger\end{array}$}} & \multicolumn{10}{|c|}{ Term births } \\
\hline & & & & & & \multicolumn{5}{|c|}{$\begin{array}{l}\text { Maternal HIV-1 RNA at delivery }<400 \mathrm{cp} / \mathrm{mL} \\
\text { N=2659 } \dagger\end{array}$} & \multicolumn{5}{|c|}{$\begin{array}{l}\text { Maternal HIV-1 RNA at delivery } \geq 10000 \mathrm{cp} / \mathrm{mL} \\
\mathrm{N}=340 \dagger\end{array}$} \\
\hline & \multicolumn{2}{|c|}{ Initial model $^{\dagger \dagger}$} & \multicolumn{3}{|c|}{ Final model } & \multicolumn{2}{|c|}{ Initial model $^{\dagger \dagger}$} & \multicolumn{3}{|c|}{ Final model } & \multicolumn{2}{|c|}{ Initial model $^{\dagger \dagger}$} & \multicolumn{3}{|c|}{ Final model } \\
\hline & OR a & $95 \%$ CI & OR a & $95 \%$ CI & $\mathrm{p}$ & OR a & $95 \% \mathrm{CI}$ & OR a & 95\% CI & $\mathrm{p}$ & OR a & $95 \% \mathrm{CI}$ & OR a & $95 \%$ CI & $\mathrm{p}$ \\
\hline \multicolumn{16}{|l|}{ Gestational age at delivery, wk } \\
\hline$<33$ week & 3.25 & $(1.32-8.03)$ & 3.37 & $(1.40-8.11)$ & 0.019 & & & & & & & & & & \\
\hline $33-36$ & 0.84 & $(0.35-2.03)$ & 0.85 & $(0.35-2.03)$ & & & & & & & & & & & \\
\hline$\geq 37$ & 1 & $*$ & 1 & & & & & & & & & & & & \\
\hline \multicolumn{16}{|l|}{ Maternal HIV-1 RNA at delivery } \\
\hline$\geq 10000 \quad$ copies $/ \mathrm{mL}$ & 9.36 & $(4.90-17.87)$ & 9.82 & $(5.24-18 . .37)$ & $<0.001$ & & & & & & & & & & \\
\hline$\overline{1000-9999}$ & 2.46 & $(1.19-5.09)$ & 2.52 & $(1.25-5.11)$ & & & & & & & & & & & \\
\hline 400-999 & 1.13 & $(0.33-3.90)$ & 1.14 & $(0.33-3.90)$ & & & & & & & & & & & \\
\hline$<400$ & 1 & $* *$ & 1 & & & & & & & & & & & & \\
\hline Active drug use & & & & & & $\S$ & & & & & & & & & \\
\hline Yes & 1.11 & $(0.24-5.13)$ & & & & & & & & & 2.11 & $(0.31-14.48)$ & & & \\
\hline No & 1 & NS & & & & & & & & & 1 & NS & & & \\
\hline \multicolumn{16}{|l|}{ Geographical origin } \\
\hline Sub-Saharan Africa & 1.70 & $(0.94-3.10)$ & 1.61 & $(0.92-2.83)$ & 0.094 & 1.20 & (0.39-3.69) & & & & 1.69 & $(0.53-5.40)$ & & & \\
\hline Other origin & 1 & $\$ \$$ & 1 & & & 1 & NS & & & & 1 & NS & & & \\
\hline \multicolumn{16}{|l|}{ Gestational age at booking, wk } \\
\hline 3rd trimester ( $\geq 28$ week) & 1.97 & $(0.93-4.15)$ & 1.95 & $(0.93-4.04)$ & 0.18 & 0.64 & $(0.13-3.19)$ & & & & 6.54 & $(1.32-32.31)$ & 8.53 & $(1.93-37.59)$ & 0.010 \\
\hline 2nd trimester (14-27) & 1.17 & $(0.64-2.13)$ & 1.15 & $(0.64-2.09)$ & & 0.40 & $(0.13-1.21)$ & & & & 5.30 & $(1.36-20.72)$ & 6.08 & $(1.66-22.26)$ & \\
\hline 1st trimester $(<14)$ & 1 & $\$$ & & & & 1 & NS & & & & 1 & $*$ & 1 & & \\
\hline \multicolumn{16}{|c|}{ Maternal CD4 cell count at delivery } \\
\hline$<200$ cells $/ \mathrm{mm}^{3}$ & 1.79 & $(0.88-3.62)$ & 1.92 & $(0.98-3.79)$ & 0.17 & 3.4 & $(0.8-14.1)$ & & & & 0.79 & $(0.23-2.72)$ & & & \\
\hline $200-349$ & 1.15 & $(0.61-2.18)$ & 1.22 & $(0.65-2.27)$ & & 1.7 & $(0.5-5.7)$ & & & & 1.35 & $(0.45-4.04)$ & & & \\
\hline$\geq 350$ & 1 & NS & 1 & & & 1 & NS & & & & 1 & NS & & & \\
\hline \multicolumn{16}{|l|}{ Gender of neonate } \\
\hline Female & 1.98 & (1.16-3.35) & 1.98 & $(1.17-3.35)$ & 0.011 & 1.39 & $(0.52-3.69)$ & & & & 2.30 & (0.84-6.29) & 2.21 & $(0.86-5.71)$ & 0.10 \\
\hline Male & 1 & $*$ & 1 & & & 1 & NS & & & & 1 & $\$$ & 1 & & \\
\hline \multicolumn{16}{|l|}{ Mode of delivery } \\
\hline Elective Caesarean & 0.56 & $(0.29-1.06)$ & 0.49 & $(0.26-0.89)$ & 0.059 & 0.72 & $(0.24-2.16)$ & & & & 1.46 & $(0.37-5.80)$ & & & \\
\hline Emergency Caesarean & 0.90 & $(0.46-1.76)$ & 0.81 & $(0.42-1.56)$ & & 0.95 & $(0.23-3.89)$ & & & & 2.59 & $(0.65-10.32)$ & & & \\
\hline Vaginal delivery & 1 & $\$$ & 1 & & & 1 & NS & & & & 1 & & & & \\
\hline Duration of antenatal ART, wk & & & & & & & & & & & & & & & \\
\hline For each increment week $\ddagger$ & 0.96 & $\begin{array}{l}(0.94-0.99) \\
* *\end{array}$ & 0.97 & $(0.94-0.99)$ & 0.010 & 0.93 & * $(0.88-0.99)$ & 0.94 & $(0.90-0.99)$ & 0.031 & 0.98 & $\begin{array}{l}(0.94-1.02) \\
N S\end{array}$ & & & \\
\hline
\end{tabular}


Last antenatal ART

\section{HAART \\ Dual-drug therapy}

Monotherapy

Intrapartum prophylaxis

\section{No}

Yes

$$
\begin{array}{cc}
1.22 & (0.56-2.67) \\
1.09 & (0.48-2.47) \\
1 & N S
\end{array}
$$

$1.60 \quad(0.66-3.89)$

1 NS $\begin{array}{ll}1.20 & (0.22-6.67) \\ 1.31 & (0.23-7.44)\end{array}$

1 NS

$\S$
$4.01 \quad(0.98-16.38)$

$2.08 \quad(0.45-9.71)$

$\$$

3.99 (1.09-14.65)

$1 *$

$0.96 \quad(0.30-3.04)$
$1.12(0.22-5.71)$
Dual or HAART
1 NS
$1 \quad N S$

$\mathrm{N}$ indicates the number of subject included in final logistic regression. ORa = adjusted odds ratio ; 95\%CI = "95\% confidence interval” .

$\dagger+$ The initial model included all variables listed in the table and also birth date, maternal age and parity.

P-values in the initial models are indicated by: ** $\mathrm{p}<0.01 \quad * 0.01 \leq \mathrm{p}<0.05 \quad \$ \$ 0.05 \leq \mathrm{p}<0.10$

$\$ 0.10 \leq \mathrm{p}<0.25 \quad N S \mathrm{p}>0.25$

$\S$ The variable could not be included in the initial model since no transmission occurred in one category

‡ Odds ratio was given for each increment week

ART=antiretroviral therapy, HAART=highly active antiretroviral therapy. 
Fig 1 - MTCT rates according to HIV RNA level at delivery - The ANRS French Perinatal Cohort (1997-2004)

Estimations were based on 5074 available data among the 5271 included mother-child pairs who received antenatal ART and did not breastfed

HIV-1 PCR in the first 3 days was not available for 12 among 52 term born infected neonates and 7 among 15 premature infected neonates

\% MTCT

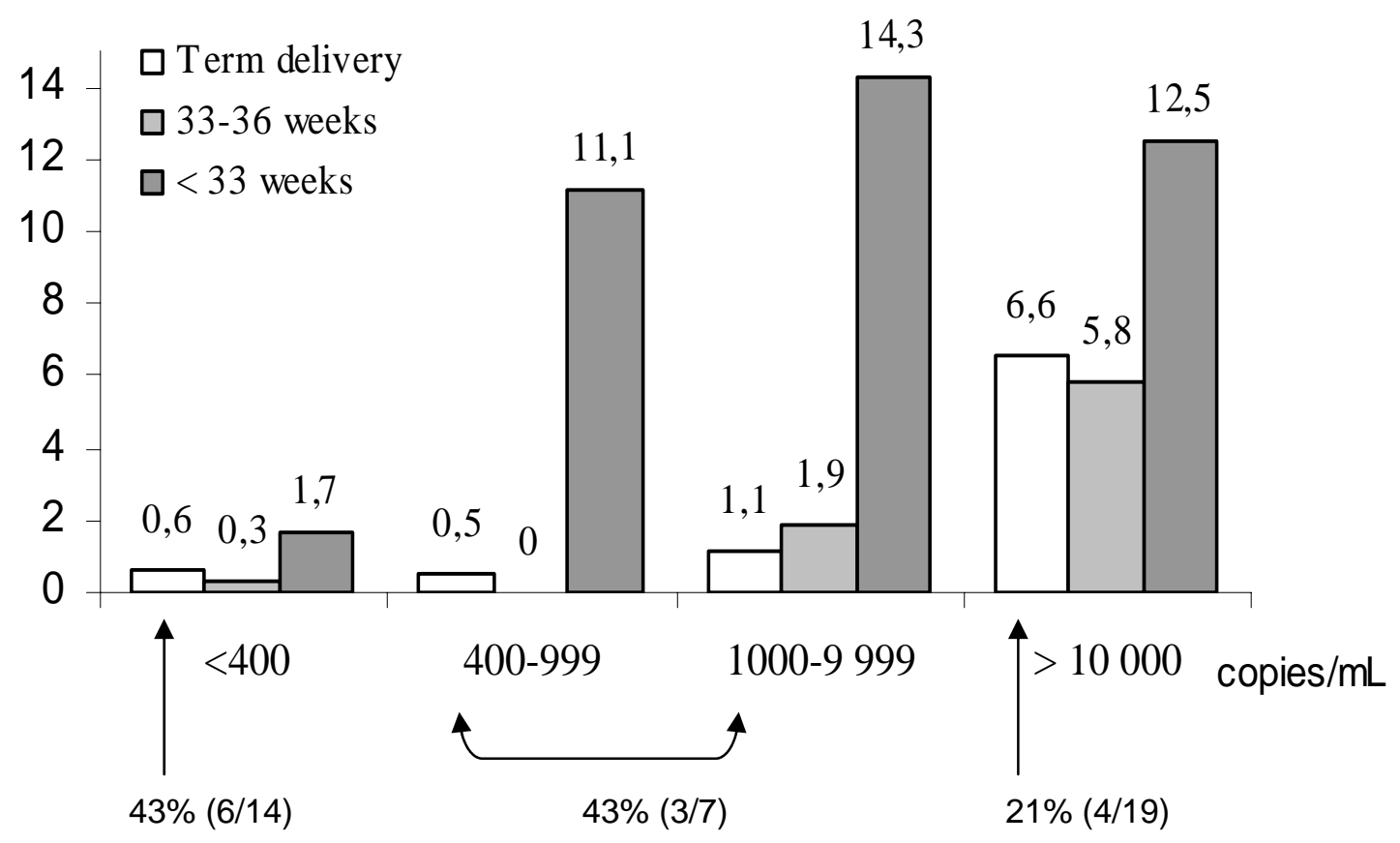

Percentage of in utero transmission in term delivery (based on positive HIV1 PCR within 3 days after birth available for 40 of 52 term births) 
Fig 2 - Relationship between duration of ART during pregnancy and MTCT rate. The ANRS

\section{French Perinatal Cohort (1997-2004)}

The curve was estimated by a generalized additive model (GAM) with a non linear term (splines).

The model was based on 5235 available data among the 5271 included mother-child pairs who received antenatal therapy and did not breastfed.

Plain line: all births ( $\mathrm{N}=5$ 235)

Dotted line: term births (37 weeks or more) $(\mathrm{N}=4554)$.

Bold dotted line : term births (37 weeks or more) and maternal HIV-1 RNA $<400 \mathrm{c} / \mathrm{mL}(\mathrm{N}=$ 2840).

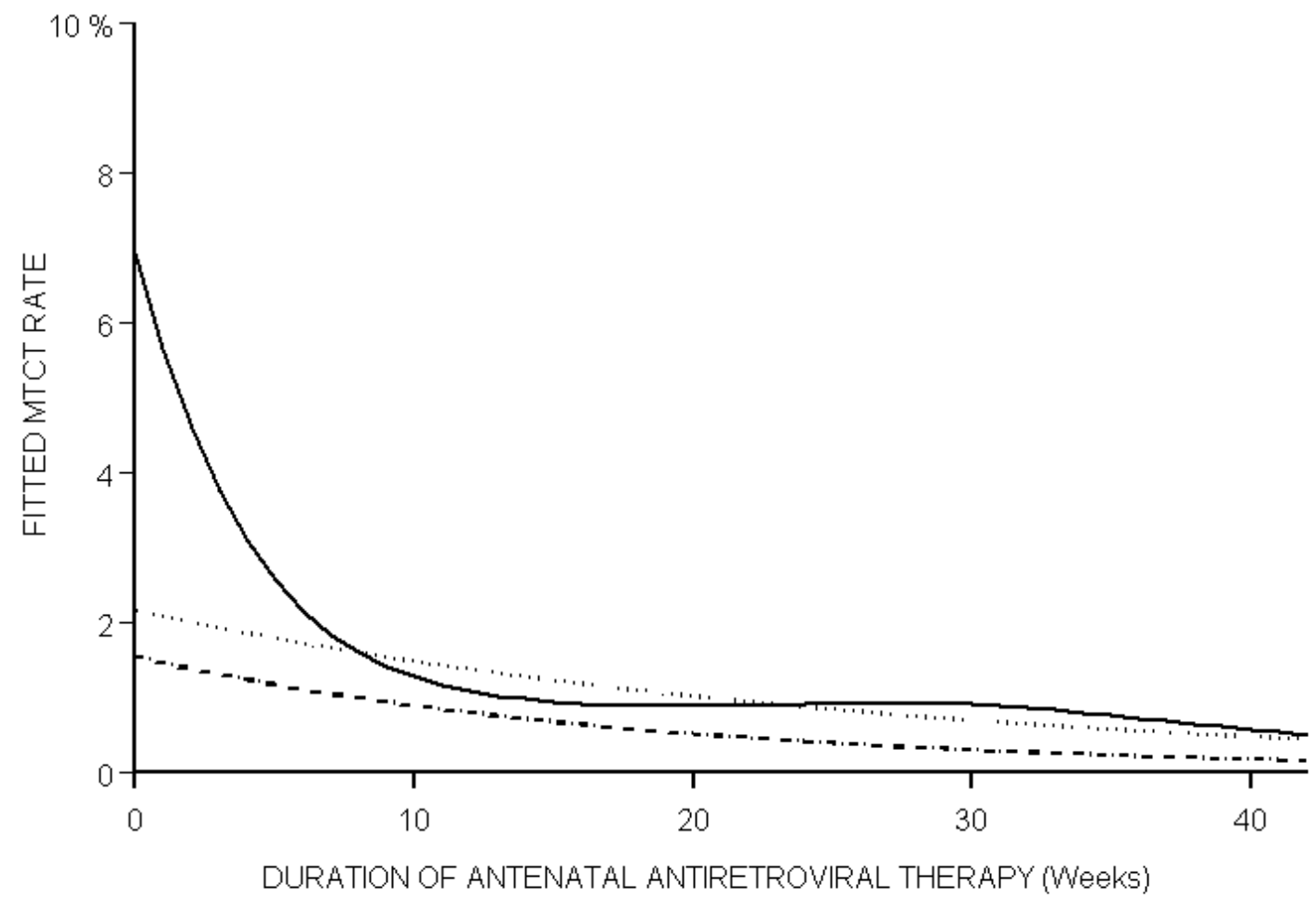


